Supplement of

\title{
Could phenological records from Chinese poems of the Tang and Song dynasties (618-1279 CE) be reliable evidence of past climate changes?
}

Yachen Liu et al.

Correspondence to: Zexing Tao (taozx.12s@igsnrr.ac.cn)

The copyright of individual parts of the supplement might differ from the article licence. 


\section{S1: The original verses and sources of the poems in Chinese used in this paper.}

1. “微月初三夜，新蝉第一声”（[唐]白居易《六月三日夜闻蝉》）；

2. “百泉冻皆咽，我吟寒更切”（[唐]刘驾《苦寒吟》）；

3. “北风卷地白草折，胡天八月即飞雪”（[唐]岑参《白雪歌送武判官归京》）;

4. “仍说秋寒早，年年八月霜”（[宋]司马光《晋阳三月未有春色》）；

5. “乡村四月闲人少，才了䖯桑又插田”（[宋]翁卷《乡村四月》）；

6. “梅信初传冬未深，高门熊梦庆相寻”（[宋]胡寅《吴守生朝》）；

7. “江涵秋影雁初飞，与客携壶上翠微”（[唐]杜牧《九日齐山登高》）;

8.“泛此黄金花，颓然清歌发”([唐]李白《忆崔郎中宗之游南阳遗吾孔子琴抚之潜然感旧》);

9. “尊前柏叶休随酒，胜里金花巧耐寒”（[唐]杜甫《人日两首其二》）;

10. “黄帝术，玄妙美金花”（[唐]吕岩《忆江南》其三）；

11. “赤霄玄戋须往来，翠尾金花不辞辱”（[唐]杜甫《赤霄行》）；

12.“澹荡韶光三月中，牡丹偏自占春风”（[唐]权德與《和李中丞慈恩寺清上人院牡丹花 歌》) ;

13.“今年杜鹃花落子规啼，送春何处西江西”（[唐]白居易《送春归（元和十一年三月三十日 作)》)；

14. “田家少闲月，五月人倍忙。夜来南风起，小麦覆陇黄”（[唐]白居易《观刈麦》）；

15. “灞桥烟柳知何限，谁念行人寄一支”（[宋]陆游《秋夜怀吴中》）；

16. “故园今日海棠开, 梦入江西锦绣堆”（[宋]杨万里《春晴怀故园海棠二首》）;

17. “碧鸡海棠天下绝，枝枝似染猩猩血”（[宋]陆游《海棠歌》）；

18. “竹外桃花两三枝，春江水暖鸭先知”（[宋]苏轼《惠崇春江晚景》）；

19. “莱洲频度浅，桃实几成圆”（[唐]卢照龄《于时春也慨然有江湖之思寄赠柳九陇》）；

20. “人间四月芳菲尽，山寺桃花始盛开”（[唐]白居易《题大林寺》）；

21. “桃花欲落柳条长，沙头水上足风光。”（[唐]刘宪《上巳日袯初渭滨应制》）;

22. “柳条弄色不忍见，梅花满枝空断肠”（[唐]高适《人日寄杜二拾遗》）；

23. “故人千万里，新蝉三两声”（[唐]白居易《立秋日曲江忆元九》）；

24. “要信今年春事早，社前十日燕新来”（[宋]陆游《新燕》）；

25. “学嚬齐柳嫩, 妍笑发春丛”（[唐]许敬宗《奉和登陕州城楼应制》）; 
26. “接天莲叶无穷碧, 映日荷花别样红”（[宋]杨万里《晓出净慈寺送林子方》）;

27. “向浦回舟萍已绿，分林蔽殿槿初红”（[唐]沈全期《兴庆池侍宴应制》）;

28. “满街杨柳绿丝烟，画出清明二月天”（[唐]韦庄《鄜州寒食城外醉吟》）；

29.“曲池苔色冰前液，上苑梅香雪里娇” ( [唐]崔日用《奉和人日重宴大明宫恩赐彩缕人胜应 制》);

30.“只为来时晚，花开不及春”（[唐]孔绍安《侍宴咏石榴》）;

31.“柳色迎三月，梅花隔二年”（[唐] 李百药《奉和初春出游应令》）；

32.“柳影冰无叶，梅心冻有花”（[唐] 李世民《冬日临昆明池》）；

33.“舒桃临远骑，垂柳映京营”（[唐]禇亮《奉和禁苑饯别应令》）；

34.“独有南山桂花发，飞来飞去袭人裾”（[唐]卢照邻《长安古意》）；

35.“月宫清晚桂，虹梁绚早梅”（[唐] 许敬宗《奉和过慈恩寺应制》）；

36.“上苑梅花早，御沟杨柳新”（[唐]骆宾王《西行别东台详正学士》）；

37.“柳色摇岁华，冰文荡春照”（[唐]卢照龄《七日登乐游故墓》）；

38.“梦梓光青陛，秾桃蔼紫宫”（[唐]刘神之《奉和太子纳妃太平公主出降》）；

39.“映水轻苔犹隐绿，缘堤弱柳未舒黄”（[唐]马怀素《奉和立春游苑迎春应制》）;

40.“彩蝶黄莺未歌舞，梅香柳色已矜夸”（[唐]李显《立春日游苑迎春》）；

41.“梅香欲待歌前落，兰气先过酒上春”（[唐]卢藏用《奉和立春游苑迎春应制》）；

42.“林中受草才生蕙，殿里争花并是梅”（[唐]沈佺期《奉和立春游苑迎春》）;

43.“剪绮裁红妙春色，宫梅殿柳识天情”（[唐]崔日用《奉和立春游苑迎春应制》）；

44.“借问桃将李，相乱欲何如”（[唐]上官婉儿《奉和圣制立春日侍宴内殿出翊彩花应制》)；

45.“金阁妆新杏，琼䇥弄绮梅”（[唐]宋之问《奉和立春日侍宴内出剪彩花应制》）;

46.“拂树添梅色，过楼助粉妍”（[唐]李峤《游禁苑陪幸临渭亭遇雪应制》）；

47.“今日回看上林树，梅花柳絮一时新”（[唐]赵彦昭《苑中人日遇雪应制》）;

48.“山花缇绮绕，堤柳幔城开”（[唐]沈佺期《奉和晦日驾幸昆明池应制》）；

49.“节䀲营全落，春迟柳暗催”（[唐]宋之问《奉和晦日幸昆明池应制》）；

50.“野花飘御座，河柳拂天杯”（[唐]沈佺期《三日梨园侍宴》）;

51.“泛桂迎尊满，吹花向酒浮”（[唐]李显《九月九日幸临渭亭登高得秋字》）;

52.“寒尽梅犹白，风迟柳未黄”（[唐]宗楚客《正月晦日侍宴沪水应制赋得长字》）;

53.“千行发御柳，一叶下仙筑”（[唐]张说《侍宴浐水赋得浓字》）；

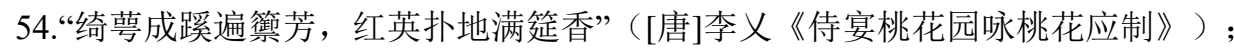


55.“红蓦竞燃春苑曙, 莑茸新吐御䇥开”（[唐]赵彦昭《侍宴桃花园咏桃花应制》）；

56.“桃花灼灼有光辉，无数成蹊点更飞”（[唐]苏䞠《侍宴桃花园咏桃花应制》）;

57.“源水丛花无数开，丹跗红蓦间青梅”（[唐]徐彦伯《侍宴桃花园》）；

58.“林间艳色骄天马，苑里秾华伴丽人”（[唐]张说《桃花园马上应制》；

59.“上阳柳色唤春归，临渭桃花拂水飞”（[唐]张说《奉和圣制初入秦川路寒食应制》）;

60.“芳春桃李时，京都物华好”（[唐]崔湜《饯唐州高使君赴任》）；

61. “香萝媚红滋，垂条索绿丝”（[唐]徐彦伯《饯唐州高使君赴任》）；

62. “宫梅间雪祥光遍，城柳含烟淑气浓”（[唐]阎朝隐《奉和圣制春日幸望春宫应制》）；

63.“轻丝半拂朱门柳，细颉全披画阁梅”（[唐]李适《奉和春日幸望春宫应制》）；

64.“光风摇动兰英紫, 淑气依迟柳色青”（[唐]崔日用《奉和圣制春日幸望春宫应制》）;

65.“晴风丽日满芳洲，柳色春筵袚锦流”（[唐]徐彦伯《上巳日袯初渭滨应制》）；

66.“宝马香车清渭滨，红桃碧柳初堂春”（[唐]沈佺期《上巳日袯初渭滨应制》）；

67.“向浦回舟萍已绿，分林蔽殿槿初红”（[唐]沈佺期《兴庆池侍宴应制》）；

68.“美人含遥霭, 桃李芳自薰”（[唐]徐彦伯《题东山子李适碑阴二首》）；

69.“独有归闲意，春庭伴落梅”（[唐]苏顽《和黄门舅十五夜作》）；

70.“何当桂枝擢，还及柳条新”（[唐]张子容《长安早春》）；

71.“暮春三月日重三，春水桃花满初潭” ( 唐]张说《三月三日定昆池奉和萧令得潭字韵》);

72.“酒䇥嫌落絮，舞袖怯春风”（[唐]王维《三月三日勤政楼侍宴应制》）；

73.“杨花雪落覆白苹，青鸟飞去衔红巾”（[唐]杜甫《丽人行》）；

74.“安得健步移远梅，乱插繁花向晴吴”（[唐]杜甫《苏端薛复䇥简薛华醉歌》）；

75.“千条嫩柳枝条垂拂青琐，百啭黄莺鸣叫声绕建章”（[唐]贾至《早朝大明宫呈两省僚 友》) ;

76.“五夜漏声催晓箭，九重春色醉仙桃”（[唐]杜甫《奉和贾至舍人早朝大明宫》）;

77.“桃花细逐杨花落，黄鸟时兼白鸟飞”（[唐]杜甫《曲江对酒》）；

78.“梨花度寒食, 客子未春衣”（[唐]钱起《下第题长安客舍》）；

79.“步屧随春风，村村自花柳”（[唐]杜甫《遭田父泥饮美严中丞》）；

80.“春城无处不飞花，寒食东风御柳斜”（[唐]韩翃《寒食》）；

81.“仲月风景暖，禁城花柳新”（[唐]李亨《中和节赐百官燕集因示所怀》）；

82.“杨柳先飞絮，梧桐续放花”（[唐]元稹《咏廿四气诗 清明三月节》）； 
83.“深竹与清泉, 家家桃李鲜” ([唐]权德與《奉和崔阁老清明日候许阁老交直之际辱裴阁老 书招云与考功苗曹长先城南游览独行口号因以简赠》）；

84.“助君行春令，开花应清明”（[唐]白居易《答桐花》）；

85.“怅望慈恩三月尽，紫桐花落鸟关关”（[唐]白居易《酬元员外三月三十日慈恩寺相忆见 寄》) ;

86.“故人千万里，新蝉两三声”（[唐]白居易《立秋日曲江忆元九》）；

87.“数日非关王事系，牡丹花尽始归来”（[唐]白居易《醉中归周至》）；

88.“九月降霜秋早寒，禾穗未熟皆青乾”（[唐]白居易《杜陵舅》）；

89.“画栏桂树悬秋香，三十六宫土花碧”（[唐]李贺《金铜仙人辞汉歌》）;

90.“杨花榆英无才思，惟解漫天作雪飞”（[唐]韩愈《晚春》）；

91.“遮莫杏园胜别处，亦须归看傍村花”（[唐]王建《寒食忆归》）；

92.“中庭地白树栖鸦，冷露无声湿桂花”（[唐]王建《十五夜望月》）;

93.“鸥鸟似能齐物理，杏花疑欲伴人愁”（[唐]罗隐《清明日曲江怀友》）; 